\title{
Review of Joshua Obuhatsa's Values Education, African Tradition and Christianity
}

\section{TITLE: Values Education, African Tradition and Christianity}

\author{
Author: Joshua Obuhatsa
}

\section{Saarbrucken, Germany: LAP Lambert Academic \\ Publishing, 2012}

\author{
(289 pages) \\ Reviewed by Humphrey J. Ojwang \\ Institute of Anthropology, Gender and African Studies \\ University of Nairobi, Kenya \\ hjojwang@yahoo.com
}

DOI: $\underline{\text { http://dx.doi.org/10.4314/tp.v6i1.8 }}$

Thought and Practice: A Journal of the Philosophical Association of Kenya (PAK)

New Series, Vol.6 No.1, June 2014, pp.85-89

thoughtandpractice@gmail.com

http://ajol.info/index.php/tp/index

ISSN: 2076-7714 
The interface between religion and culture forms the core of this significant work by Prof. Joshua Obuhatsa of the Pan African Christian University. The writer currently teaches General Education at this pioneer Pentecostal Institution of higher learning based in Nairobi, Kenya. His background as a professional teacher and curriculum developer, with over 30 years work experience in the Kenyan educational sector, puts him in a unique position to conduct a critical discourse analysis of the texts which constitute the educational narrative of the republic of Kenya specifically, and Africa in general.

I knew the author of this book on the Kenyan educational experience in the mid 1970s when he was a teacher trainer at the Siriba Teachers College in Maseno Town in Western Kenya. He belongs to the neo-Pentecostal renewal movement which had its roots in Maseno. One of the leaders of the movement was a British missionary and educationist, the Revd Cythbert $\mathrm{H}$. Dawkins, who founded the Trinity Fellowship in Maseno Town, a Christian movement which had a profound influence on educational institutions in Western Kenya. It is noteworthy that the impact of this neo-Pentecostal movement informed the world-view of Prof. Obuhatsa from a very early stage, culminating in this publication. Maseno Town was an important centre of the Church Missionary Society (an outfit of the Church of England) which started educational work in western Kenya in 1906 by establishing what is known today as Maseno National School. Later, Siriba Teachers College, the Veterinary Training School, and a missionary hospital were established, with Government offices providing administrative services in the region. Maseno became an important reference point in the Anglican Church in Kenya. I had the good fortune of attending Maseno National School in the mid 1970's; I also taught there in the early 1980s.

Prof. Obuhatsa attended local schools in Bunyore area of the Bantu-speaking Luhya community to the North of the Equator before training as a school teacher in Siriba College. He later joined the University of Nairobi for a B.A (Education Option) degree, with Christian Religious Education as one of his teaching subjects. After many years of teaching in Kenyan schools and colleges, Prof. Obuhatsa worked with the Christian Education affiliate of the ecumenical movement National Council of Churches of Kenya for some years as a curriculum developer and instructional materials designer based at the Church House, Nairobi. He later won a scholarship to the University of London's Institute of Education, where he earned a Master of Arts (Education) degree in 1991 with a dissertation investigating 
whether Christian Religious Education in Kenyan schools incorporated social and moral values in the curriculum. His conclusion in the study was that contextualization of social and moral values was not considered in the curriculum development of the subject, and that this 'gap' needed attention if Christian Religious Education was to have any meaningful contribution to the Kenyan society.

Prof. Obuhatsa's book under review is based on the research he conducted for his Doctor of Philosophy degree awarded by the University of London's Institute of Education in the year 2000. His quest for social and moral values seems to hinge on a captivating theological narrative which draws effectively from different traditions, namely, African culture, Evangelicalism, Pentecostalism and neo-pentecostalism (or Charismatism), with a tinge of the Nyayoism of the former President of Kenya, Daniel T. arap Moi whose political "philosophy" derived from nyayo (Kiswahili for 'footprints') which highlights the Christian concepts of love, peace and unity, was his slogan during his autocratic reign from 1978 to 2002. Nyayoism was discredited in Kenya in 2002, when Moi's Kenya African National Union was swept from power through an alliance of forces led by Mwai Kibaki and Raila Amolo Odinga.

Central to the book is the idea of 'contexts', referring to circumstances in which educational activities happen and are considered. Thus political, economic and social trends must be taken into consideration when inculcating social and moral values in the curriculum of Christian religious Education. Closely related to context is the notion of perspective. The author seems to take the critical discourse perspective in the tradition of narrative ethnography, based on two influential Government reports in the 1960's and 1970's as the benchmarks of educational policy formulation in Kenya. The author confesses that he had the privilege of being part of a church delegation to former President Daniel Arap Moi, and heard him "rehearse some of the important connections between the state and the churches in Kenya's educational development" (p.21).

The author concedes that one of the problems he faced was being part of the context he was writing about, and was therefore faced with the temptation of partiality:

"Any one in my position might suffer a similar difficulty. But this does not necessarily put me in a disadvantageous position; in the contrary it may help me to be more precise, relevant and objective in my presentation (p.25). 
This position is reminiscent of Davidson Nicol's dilemma when he wrote his seminal work titled Africa: A subjective view in 1964. In this insightful book, Nicol, who was the former Principal of Fourah Bay College in Sierra Leone, West Africa, covered a number of themes on Africa, namely, politics, public services, writers and critics, and schools, colleges and universities. He conceded that as an African writing about Africa, he could only give a subjective view as an insider.

In giving an ethnographic account of the people groups who settled in present day Kenya centuries ago, Prof. Obuhatsa mentions Bantu-speaking groups, namely, the Kikuyu, Kamba, Luhya, Kisii, Kuria, Mijikenda and Pokomo, among others. He asserts that the Luhya are said to be the representative group of the Bantu cultures, with the meaning of their name being 'those of the same group'. He further states that the Luhya had politically well-organised groups, with strongly religious values and taboos of various kinds regulating relationships in the community. In my considered opinion, it is in this context that the author's subjectivity is most glaring, when he refers to the Luhya as the most "representative group of Bantu cultures". Whatever attributes he assigns to the Luhya people are true of all other Bantu groups in East Africa. This is typically what a scholar might suffer from if he or she engages in auto-ethnography, of the kind Jomo Kenyatta institutionalised in his two accounts of the traditions and customs of the Mount Kenya Bantu groups in Facing Mount Kenya and My People the Agikuyu, where he put together the Kikuyu with the Embu and Meru people. This is what was later used to build a hegemonic edifice for political expediency in postIndependence Kenya, when Jomo Kenyatta and his power-elite formed Gikuyu, Embu and Meru Association (GEMA) which is more of a politico-economic grouping rather than an ethno-linguistic category.

Another glaring omission in this book is a major ethno-linguistic group known as the Luospeaking people. Their language belongs to the Nilo-Saharan classification, and they are the most visible Nilotic speaking group in Kenya, Uganda and Tanzania, with the bulk of them settled around Lake Victoria. Luo culture, music, sports and politics have dominated the National Heritage of Kenya for many decades. The migration and settlement of the Luo from southern Sudan to the three East African territories was robustly presented in History of Southern Luo by the well-known historian Prof. Bethwell Allan Ogot after he successfully defended his Doctor of Philosophy thesis at the School of Oriental and African Studies at the University of London in the mid-1960s. A seminal work in literature covering the same 
period was The Promised Land and other short stories by Grace Ogot (wife of Prof. Bethwell Allan Ogot) which covered the social and moral values of the day. Prof. Obuhatsa seems to lean more towards the other Nilotic-speaking group known as the Kalenjin (sub-groups: the Kipsigis, Nandi, Sabaot, Tugen, Elgeyo, Marakwet and Pokot), since they practice the ritual of male circumcision and allegedly "tend to be more committed to their ethnic groups in terms of identity" (p.84). Incidentally, the Luo-speaking peoples of Eastern Africa do not practice the ritual of male circumcision. This could have been one of the reasons for their exclusion from the discussion of the social and moral values which the author considered significant in his work. Be that as it may, the author tries to explore African traditions and customs, and how they can give Christian Religious Education contextual relevance. Thus he tries to integrate African socialism and Judeo-Christian values, depicting them as jointly forming the core of the values of future generations. He concludes that education must be understood in a holistic manner in Kenya's unique context.

The most significant concept that the author has established in Values Education, African Tradition and Christianity is what may be called contextual theology. He contends that for any programme of Christian Religious Education, contextual theology must inform the process of curriculum development and be alive to the external influences from former European colonizers and internal influences of indigenous traditions of the African peoples. There is room for further research and reflection on this concept of contextualization of theology and the process of enculturation when teaching social and moral values in Kenyan schools and colleges. This book will definitely inform the philosophy of education in Kenya, with specific reference to social and moral values.

With my experience of over 25 years teaching educationists and social anthropologists in a large secular institution of higher learning, I wish to recommend this book for use in our teacher training colleges and universities. The book will be useful to students, academic staff, researchers, policy analysts, curriculum developers, and social scientists who are interested in how education, religion and culture have contributed to the shaping of the Kenyan society. It is a must read for all searching minds in the humanities and social sciences interested in African studies. 